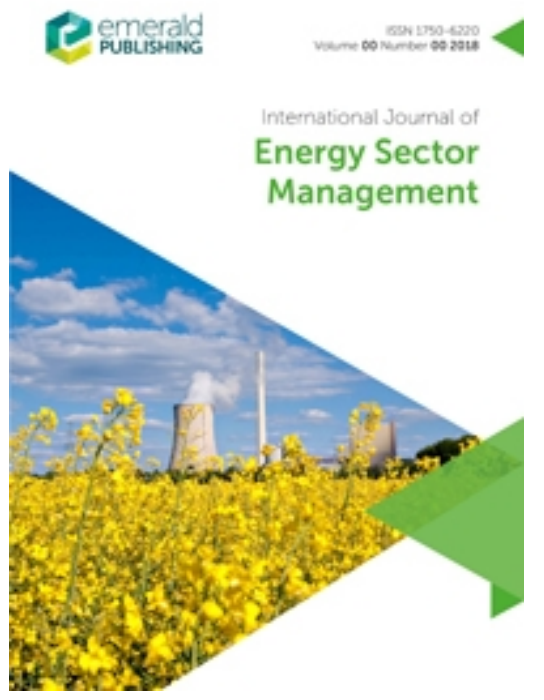

\title{
Identifying and prioritizing delay factors in Iran's oil construction projects
}

\begin{tabular}{|r|l|}
\hline Journal: & International Journal of Energy Sector Management \\
\hline Manuscript ID & IJESM-04-2020-0006.R2 \\
\hline Manuscript Type: & Research Papers \\
\hline Subject Area: & Project management, Construction, Delay factors, Decision making \\
\hline Methods/ Tools / Analytical \\
Frameworks: & Multi-criteria decision-making, Fuzzy Delphi method, Best-Worst method \\
\hline \multicolumn{2}{|c}{} \\
\hline
\end{tabular}

\section{SCHOLARONE ${ }^{m}$ \\ Manuscripts}




\title{
Identifying and prioritizing delay factors in Iran's oil construction projects
}

\begin{abstract}
Purpose- Successful implementation of construction projects is one of the crucial factors for the economic development of every country. The main part of the countries' capital is allocated to civil and infrastructure projects annually, most of which are accomplished with delay. Construction projects are often criticized for overrunning time and budgets. Analyzing the factors causing delay is essential for omitting them and timely implementation of these projects. Due to the importance of oil projects, in this research, the factors causing a delay in Iran's oil construction projects are investigated and analyzed.

Design/methodology/approach- In this study, after a broad literature review, using fuzzy Delphi method (FDM), a total of 75 delay factors were identified under 11 major categories of owner, contractor, consultant, equipment, labor, materials, design, contract and contractual relations, laws and regulations, environmental factors, and managerial factors. Then, by employing the best-worst method (BWM), the factors were prioritized.

Findings- The results showed that sanction, governmental management systems, weak project management by the contractor, technical and managerial weaknesses of the consultant, financial problems and delay in payment by owner, low efficiency of the equipment, low productivity of the workforce, changes in laws and regulations, inappropriate organizational structure linking to the project, changes in the design, and changes in the price of materials are the most crucial factors causing delay in the Iran's oil construction projects.

Research implications- These findings are expected to have significant contributions to Iran's oil construction industry in controlling the time overruns in construction contracts.

Originality/value-The main contribution of this study is to develop a comprehensive framework in which, causes of delay in Iran's oil construction projects are addressed and prioritized.
\end{abstract}

Keywords Project management, Construction projects, Delay factors, Decision making 


\section{Introduction}

A construction project is generally considered successful if it is completed on time, within a budget, according to the specifications, and stakeholder satisfaction. However, most of the projects are not completed at the expected time. Instead, they are completed before or after the schedule due to many variables and unpredictable factors such as the performance of parties, availability of resources, environmental conditions, and contractual relations (Assaf and AlHejji, 2006). Delay is considered as one of the most common problems causing negative effects on construction projects and its participating parties and is often responsible for turning profitable projects into failed ventures. These delays can be avoided or reduced if the major delay factors can be identified and handled in a timely manner (Sweis et al., 2008).

Energy resources in Iran are the third largest oil reserves and the second largest natural gas reserves in the world. Iran is the most active in the oil and gas sector, accounting for more than 70 percent of the country's total project value, while most oil and gas projects are behind schedule (Fallahnezad, 2013; Zarei et al., 2017; Sweis et al., 2018b).

Complex and multi-disciplinary, large size, huge investment, long time duration, small key players in the sector, the advanced technologies being used, massive interface, special abilities and complex engineering efforts characterize the uniqueness of oil and gas projects. Managing such projects refers to the unique requirements of managing science, technology, and engineering aspects (Mohamed and Price, 2005; Salama, 2008; Sweis et al., 2018; Hadikusumo et al., 2014).

The success of construction projects in general and oil and gas projects in particular depends on identifying and defining the affecting delay factors of the project. Developing proper strategies and plans are useful to avoid any possible risk to the cost, schedule, and quality of the project. This results can help management and the project team to plan for suitable solutions to mitigate the delay factors according to the priority of occurrence and the significance (Kassem et al., 2019).

While the factors causing a delay in construction projects have been widely studied, there are few studies in the Iran's oil context, and a comprehensive study in this field is still hard to find. There are some similarities shared with construction projects; however, the factors determined in the literature as causes of delay in construction projects might not apply to oil projects. In addition, the most important causes of delay vary from one country to another. To cover this knowledge gap, the current research attempts to address the following objectives:

(1) to identify causes of delay in oil construction projects in Iran;

(2) to prioritize causes of delay in oil construction projects in Iran. 
For this purpose, causes of delay in oil construction of Iran are identified using fuzzy Delphi method (FDM) and prioritized using best-worst method (BWM). Indeed, this study proposes a process integrating FDM and BWM to engage the challenge of identification and prioritizing of delay factors in oil construction projects. The FDM effectively gathers the opinion of experts toward developing critical delay factors and meanwhile reduces the ambiguity and uncertainty existing in experts' judgments. The BWM is used to construct a structure to prioritize the selected delay factors previously identified by the FDM.

The work is structured as follows: Literature review is presented in the next section. Then research methodology is given. Afterward, findings are presented. The final section concludes the paper.

\section{Literature review}

Delay in construction projects has been attracting much attention among researchers for decades, and various aspects of delay in construction projects have been studied.

As discussed by Mohamed and Price (2005), there is a considerable similarity between the construction phase of oil and gas projects and general construction projects. However, in this section, we review the literature in two parts: a general perspective, and oil and gas projects.

\subsection{Causes of delay in construction projects: a general perspective}

Abbasi et al. (2020) investigated causes of delays in the construction industry of Iran using a cause-and-effect diagram. Causes of delays were classified in eight main groups including contractor, owner, design, procurement, equipment, consultant, and labor. Results showed that financial problems of contractor were the main factors causing delay. Delay causes of construction projects for developing Southeast Asia countries were explored by Wuala and Rarasati (2020). Base on the findings, contractor- and owner- related causes were the most crucial factors causing delay in these countries. Al Maktoumil et al. (2020) assessed causes of delay in construction projects in Oman. They reported that the owner-, equipment-, and material-related factors had a considerable impact on delay of projects. Latif et al. (2019) also reported that changes in the scope of the project, lack of communication between parties, and shortage of skilled labour were three top delay factors in Oman.

Following a statistical survey, Muneeswara et al. (2020) analyzed causes of delay in the Indian construction industry. Inadequate schedule was found to be the most critical factor. Razi et al. (2019) investigated delay causes of a road construction project in Malaysia using the analytic hierarchy process (AHP) technique. Fund risk, flood, heavy rain, unforeseen ground condition, and existing utility issue were determined as most prioritized factors. Based on a questionnaire survey, Kog (2019) reported construction delays in Indonesia, Malaysia, Thailand, and 
Vietnam. It was revealed that most of the delay factors in Indonesia and Malaysia were linked with contractors. While contractor- and owner- related factors were top delay factors in Thailand. As stated by Prasad et al. (2019), finance-related causes were the most critical causes of delay in Indian projects. Following a questionnaire survey, Alsuliman (2019) ranked causes of delay in Saudi public construction projects. Awarding tenders group was identified as the first group affecting delay. Using a hybrid fuzzy TOPSIS ${ }^{1}$ - BWM, Norouzi and Ghayur-Namin (2019) investigated and prioritized causes of delay in a railway megaproject in Iran. Inability to meet the project required standards, inappropriate planning and scheduling, and defective design were identified as the ones with the highest priority.

Hosaini and Singla (2019) determined and ranked causes of delay in construction projects in Afghanistan. Top three delay causes were ineffective planning and scheduling of a project by contractor, delay in progress payments by owner, and poor site management and supervision of contractors by consultant and owner. Based on a questionnaire survey, Sweis et al. (2018a) introduced the delay factors of strategic industrial projects in Iran. The most critical factors were sanctions, cash flow problems, equipment availability and failure, project manager competence, material procurement, and unqualified labor. Al-Hazim et al. (2017) investigated factors causing completion delay and cost overrun in infrastructure projects in Jordan. The findings showed that terrain and weather conditions were the main factors causing delay. Gebrehiwet and Luo (2017) analyzed causes of delay at different stages of construction in Ethiopian construction projects. As a result, the five most important causes of delay were identified as corruption, unavailability of utilities at site, inflation or price increases in materials, lack of quality materials, and late approval of design documents.

Following a questionnaire survey, Oyegoke and Kiyumi (2017) provided causes of delay in megaprojects in the Sultanate of Oman. Five most frequent causes of delay were selection of the lowest bid by owner, the financial condition of the main contractor, delay in decisionmaking by owner, and poor construction planning by the contractor. Delay causes of road construction projects in Egypt were explored by Aziz and Abdel-Hakam (2016). A questionnaire and personal interviews listing 293 delay causes formed the basis of the paper. Poor site management and supervision by the contractor was reported as the most crucial factors. Marzouk and El-Rasas (2014) analyzed delay causes in Egyptian construction projects. The feedback of construction experts was obtained through interviews and questionnaire surveys. Top Five delay causes were late payments for completed work, changes of order and

\footnotetext{
${ }^{1}$ The Technique for Order of Preference by Similarity to Ideal Solution
} 
scope by owner, effects of subsurface conditions, low productivity level of labors, and ineffective planning and scheduling of project.

Abbasnejad and Izadi-Moud (2013), identified construction delay factors in Iranian civil engineering projects. They concluded that the most crucial factor is lack of knowledge of the involved members of the projects about the nature of construction industry. Aziz (2013) described various numerous factors delay in construction projects in Egypt. 99 factors were short-listed to make part of the questionnaire survey and were identified and categorized into nine significant categories consisting of consultant, contractor, design, equipment, external, labor, materials, owner, and project related factors. Based on a questionnaire survey and using structural equation modelling, Doloi et al. (2012) investigated factors affecting delay in Indian construction projects. The findings highlighted the importance of the role of owner and technical expertise in planning to decrease time delays. Reasons for delay in Iranian construction projects were studied by Khoshgoftar et al. (2010). Finance and payments of completed work were identified as the most important causes of the delay.

Investigating the factors causing delay in Saudi Arabian public sector, Kharashi et al. (2009) reported that the lack of qualified and experienced personnel and associated current under supply of labor were the most influencing causes of delay. Toor and Ogunlana (2008) analysed the leading causes of delays in Thailand construction projects. Factors related to designers, contractors, and consultants were rated among the top problems. Sweis et al. (2008) identified and classified causes of construction delay in residential projects in Jordan. Financial difficulties faced by the contractor and too many change orders by owner were determined as the leading causes of construction delay. Investigating causes of delay in Vietnam large construction projects, Le-Hoai et al. (2008) reported poor site management and supervision, poor project management assistance, financial difficulties of the owner, and contractor, and design changes as the five most critical causes. Based on a survey by Faridi et al. (2007), it was reported that approval of drawings, inadequate early planning, and slow decision making by owner were the top causes of delay in UEA construction industry. A questionnaire survey was conducted by Sambasivan and Soon (2007) to identify causes and effects of delay in the Malaysian construction industry from the owners', consultants', and contractors' viewing. Five most important causes were contractor's improper planning, poor site management, and inadequate experience, inadequate owner's finance, and payments for completed work, and problems with subcontractors.

Adopting a questionnaire survey approach for understanding the risks in Indonesian construction projects, Andi (2006) identified 27 construction risks. A survey on the time performance of different types of construction projects in Saudi Arabia was conducted by Assaf 
and Al-Hejji (2006) to determine causes of delay and their importance in the view of the project participants consisting of the owner, consultant, and contractor. The most critical causes of delay in Jordanian construction projects with traditional type contracts from the viewpoint of construction, contractors, and consultants were introduced by Odeh and Battaineh (2001). The results indicated that owner interference, inadequate contractor experience, financing and payments, labor productivity, slow decision making, improper planning, and subcontractors were among the top critical factors. Supporting the finding by Al-khalil and Al-Ghafly (1999), lack of agreement among the parties was one of the root causes of delay of construction projects in the Eastern Province of Saudi Arabia. Based on a survey by Mezher and Tawil (1998), 64 causes of delay in Lebanon construction projects were identified. It was found that owners, consultants, and architectural/engineering firms generally agreed on the ranking of the significant categories of delay factors. Zakeri et al. (1996) surveyed Iranian construction operative productivity. Materials shortage, weather and site conditions, equipment breakdown, drawing deficiencies/change orders, and lack of proper tools and equipment were identified as the most problems.

\subsection{Causes of delay construction projects: oil and gas projects}

Supporting the findings by Aljamee et al. (2020), contractor due to using the lowest bidding prices was the main reason for delay in construction projects in the Iraqi petroleum and gas industry. Causes of delay in an oil and gas engineering, procurement, and construction (EPC) project in Indonesia were studied by Hatmoko and Khasani (2019). They concluded that the financial capability of contractors significantly influenced the EPC project, with an estimated delay of 33\% of the total project duration. Based on a survey by Kassem et al. (2019), internal risks, followed by changes during construction project, government instability, incorrect project cost estimation, government delay in decision making, incorrect project schedule estimation, and political situation and war were the greatest influential factors in construction projects in the Yemen oil and gas sector. Gomarn and Pongpeng (2018) investigated construction delays caused by contractors and suppliers in Thailand's oil and gas platform projects. The most critical factors were poor site management and supervision by contractors, and supply of unqualified and unskilled personnel by suppliers.

As stated by Abdullah et al. (2018), delays in subcontractor's work, lack of subcontractor skill, and poor planning and scheduling were the most crucial factors causing delay in Palm oil refinery construction projects in Malaysia. Sweis et al. (2018b) reported causes of delay in Iran's oil and gas projects using root cause analysis and under five categories consisting of financial-, operational-, site-, human and equipment-, and external- related. The operationalrelated category identified as the most effective category. Suppramaniam et al. (2018) reviewed 
and categorized causes of delay in Malaysian construction oil and gas projects in six major categories, namely owner, contractor, engineering, external, project, and resources. Zarei et al. (2017) analyzed causes of delay in the complex construction project in the oil-gaspetrochemical sector in Iran using semantic network analysis approach. Results showed that the main factor causing delay was initial negotiations deficiencies.

Causes of delay in construction projects in the oil and gas industry of the Persian Gulf cooperation council countries were investigated by Ruqaishi and Bashir (2014). Seven factors consisting of poor site management and supervision by contractors, problems with subcontractors, inadequate planning and scheduling of projects by contractors, poor management of contractors' schedules, delay in delivery of materials, lack of effective communication among the project stakeholders, and poor interaction with vendors in the engineering and procurement stages were revealed as the significant causes of project delay. Leading causes of delay in the projects of zone 3 of Iranian Gas Transmission Company were analyzed by Atafar and Eghbali (2014). For this purpose, some experts were interviewed. The results suggested a failure to fulfill obligations by the contractor as the most critical factor. Adapting a multiple case study, Pham and Hadikusumo (2014) identified factors affecting delays in EPC petrochemical projects in Vietnam. Fallahnejad (2013) determined and ranked causes of delay in 24 gas pipeline projects in Iran. Ten major delay factors were imported materials, unrealistic project duration, materials to be supplied by owner, land expropriation, change orders, contractor selection methods, payment to the contractor, obtaining permits, suppliers, and contractor's cash flow.

Ravand and Salahi (2011) examined causes of delay in the implementation of oil and gas industrial projects in Iran. The most crucial factors were weaknesses in primary studies, lack of expert labor, lack of timely funding, and contractual ambiguities. Following an interview-based questionnaire with experts, Salama et al. (2008) investigated the factors leading to time overruns in the oil and gas projects in the United Arab Emirate (UAE). Focusing on the UAE oil and gas projects, Salama et al. (2008) investigated the fundamental causes of delay employing a questionnaire-based approach. Five most important causes were delay in the start of purchasing long-lead items, delay in materials and equipment delivery, lack of experience and knowledge of contractor technical staff, poor project management by contractor, and shortage of experienced and qualified engineers. Thuyet et al. (2007) identified the main causes of delay in oil and gas construction projects in Vietnam. The major causes of delay were bureaucratic government system and long project approval procedures, poor design, incompetence of project team, inadequate tendering practices, and late internal approval processes from the owner. 
The literature review revealed that albeit considerable research has been conducted to investigate the affecting delay factors in the construction industry worldwide, only a few research has concentrated on the delay factors in oil and gas construction projects. Moreover, few studies have investigated this issue in Iran. Therefore, the current research aimed to study causes of delay in oil construction projects in Iran.

Based on the literature review, Table 1 shows causes of delay in construction projects under 10 categories namely owner, contractor, consultant, equipment, labor, materials, design, contract and contractual relations, laws and regulations, environmental factors. The frequency of each factor in the literature can be seen in column 3 .

Table 1. Delay factors in construction projects.

\begin{tabular}{|c|c|c|}
\hline Category & Delay factor & Frequency \\
\hline \multirow{13}{*}{ 1. Owner } & Financial problems and delay in payment & 39 \\
\hline & Slowness in decision making and administrative bureaucracy & 36 \\
\hline & Unrealistic contract duration & 20 \\
\hline & Delay in site delivery & 19 \\
\hline & Types of biding and rewards & 13 \\
\hline & Delay in reviewing and approving documents & 14 \\
\hline & Owner interference & 11 \\
\hline & Poor communication and coordination with other parties & 11 \\
\hline & Ineffective incentives and penalties & 9 \\
\hline & Lack of experience & 8 \\
\hline & Inappropriate feasibility study of the project & 5 \\
\hline & Delay in materials to be supplied by the owner & 5 \\
\hline & Frequent change of managers & 2 \\
\hline \multirow[t]{11}{*}{ 2. Contractor } & Problems with subcontractors & 34 \\
\hline & Financial problems & 31 \\
\hline & Inadequate experience & 30 \\
\hline & Ineffective project planning and scheduling & 29 \\
\hline & Poor site management and supervision & 28 \\
\hline & Inappropriate construction methods & 19 \\
\hline & Rework to correct undesirable work & 18 \\
\hline & Poor communication and coordination with other parties & 15 \\
\hline & Poor qualification of the contractors' technical staff & 14 \\
\hline & Weak project management & 4 \\
\hline & Improper pricing by contractors to win the bid & 5 \\
\hline \multirow[t]{6}{*}{ 3. Consultant } & Delay in reviewing and approving design, drawings and ... & 21 \\
\hline & Delay in conducting inspection and testing & 17 \\
\hline & Inadequate experience & 15 \\
\hline & Weak communication and coordination with other parties & 10 \\
\hline & Poor contract management & 8 \\
\hline & Quality assurance/control & 9 \\
\hline
\end{tabular}




\begin{tabular}{|c|c|c|}
\hline & $\begin{array}{l}\text { Ambiguities and mistakes in specifications, drawings, or } \\
\text { documents }\end{array}$ & 6 \\
\hline & Technical and managerial weaknesses & 2 \\
\hline 4. Equipment & Shortage of equipment & 26 \\
\hline & Frequent failure of equipment & 21 \\
\hline & Low efficiency of equipment & 15 \\
\hline & Lack of high-tech mechanical equipment & 7 \\
\hline & Slow mobilization of equipment & 4 \\
\hline & Inappropriate selection of equipment and faulty equipment & 2 \\
\hline 5. Labor & Shortage of labor & 32 \\
\hline & Low productivity & 32 \\
\hline & Low motivation & 6 \\
\hline & Nationality & 3 \\
\hline & Personal differences of employees & 1 \\
\hline 6. Materials & Delay in delivery of materials & 35 \\
\hline & Shortage of materials & 31 \\
\hline & Changes in price & 18 \\
\hline & Low quality & 15 \\
\hline & Changes in the type and characteristics of materials & 13 \\
\hline & Damage of stored materials & 9 \\
\hline & Problems with providing materials at current official prices & 1 \\
\hline 7. Design & Changes in design & 12 \\
\hline & Mistakes and discrepancies in design documents & 11 \\
\hline & Poor use of advanced engineering design software & 4 \\
\hline & Misunderstanding of owner requirements by design engineer & 3 \\
\hline & $\begin{array}{l}\text { Incomplete/conflicts of design drawings details and } \\
\text { specifications }\end{array}$ & 4 \\
\hline 8. Contract and & Changes in orders of contract & 11 \\
\hline contractual & Lack of communication between the parties & 10 \\
\hline relations & Major disputes and negotiations & 8 \\
\hline & Inappropriate organizational structure linking to the project & 7 \\
\hline & Mistakes and disputes in the contract documents & 6 \\
\hline 9. Laws and & Changes in laws and regulations & 20 \\
\hline regulations & Tax laws, tariffs, and customs duties & 3 \\
\hline & Weaknesses in the laws and regulations & 2 \\
\hline 10. & Weather conditions & 22 \\
\hline Environmental & Unexpected geological conditions & 18 \\
\hline factors & Inflation & 12 \\
\hline & Incidental events such as flood, earthquake, and storm & 10 \\
\hline & Economic changes such as changes in exchange rate & 8 \\
\hline & Problem with neighbors & 8 \\
\hline & Change in government policies & 3 \\
\hline & Sanction & 2 \\
\hline
\end{tabular}




\section{Research approach}

The research was conducted on three stages. Figure. 1 shows the procedure for doing this research. At the first step, previous researches were studied and reviewed, and delay factors in construction projects were categorized in different categories. In the second step, FDM was used to identify the delay factors in Iran's oil construction projects. In this regard, a questionnaire survey approach was adopted to find the main factors affecting delay in Iran's oil construction projects. After identifying the delay factors, they were prioritized by using BWM. For this purpose, another questionnaire was prepared for getting the opinion of the experts. Details of FDM and BWM are described below:

\subsection{Fuzzy Delphi method (FDM)}

The Delphi method is based on the philosophical assumption that " $n$ heads are better than one". It is a procedure designed to sample a group in order to gain the opinion of knowledgeable persons on a particular topic (Fish and Busby, 1996). The traditional Delphi method has apparent weaknesses; it is costly, time-consuming, and has a lower questionnaire return rate as it tries to lead to converged results by repetitive surveys. Furthermore, the problems of uncertainty and ambiguity again exist in experts' responses (Shen et al. 2010). To overcome these shortcomings, some studies have proposed specific optimized methods; the most representative of them is the FDM developed by Murray et al. (1985), which combines the fuzzy theory and the Delphi method. The FDM can converge experts' responses with fewer survey rounds and constructively conduct their uncertainty and ambiguity. In FDM, the experts' judgments are represented by fuzzy numbers. Then the subjective opinions are transformed into objective data through a fuzzy operation.

Project risks and delay factors have an uncertain nature, and assigning precise crisp numbers to them is not a suitable way. Fuzzy logic is quite appropriate for the task of considering the uncertain nature of risks and delay factors in construction projects based on experience and managerial subjective judgment (Tavakolan and Etemadinia, 2017). Therefore, we used FDM to obtain the delay factors for Iran's oil construction projects. The procedure of FDM used in this study is as follows: 


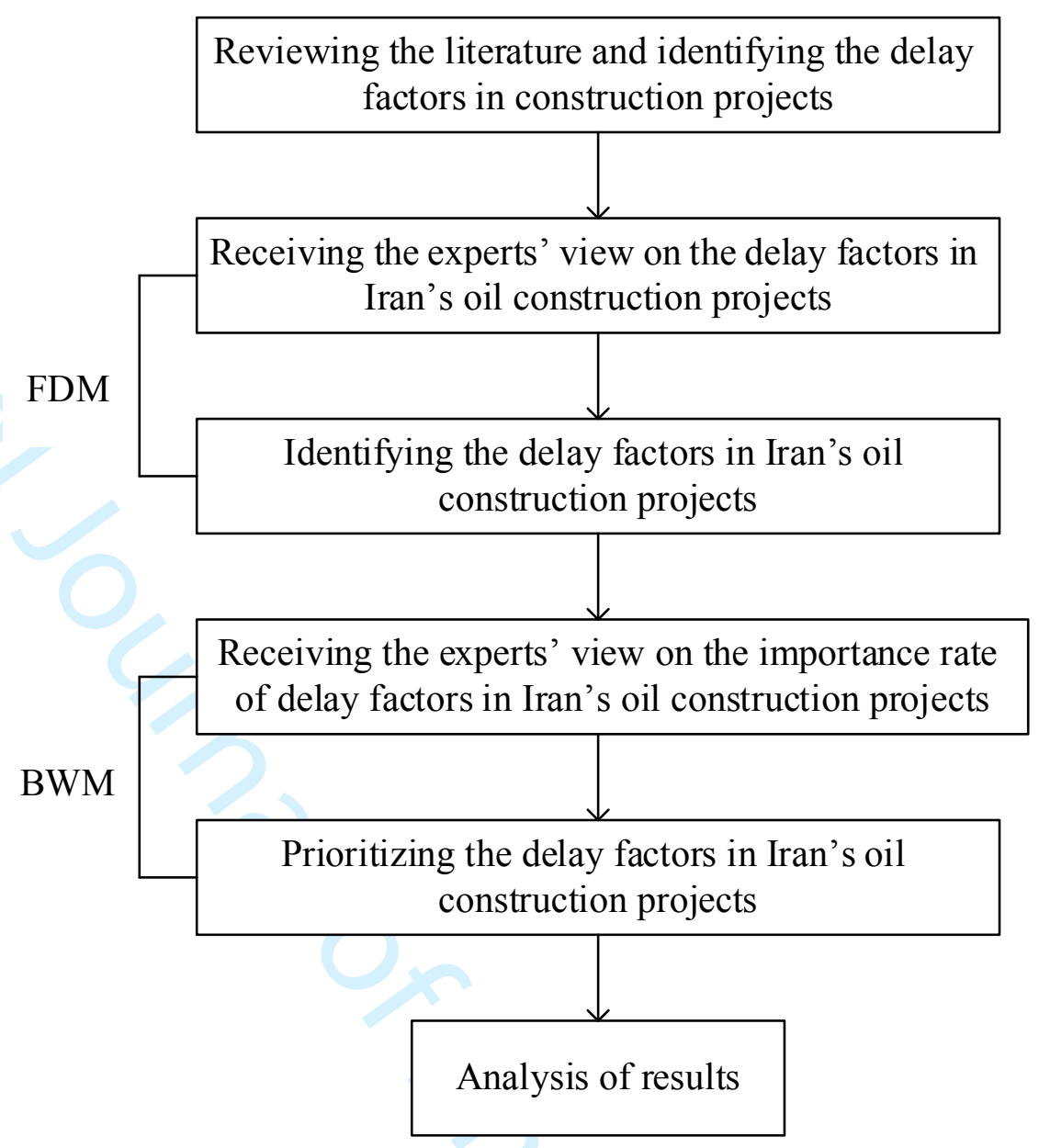

Figure. 1: The procedure of doing this research.

Step 1: Collect the opinions of experts: A questionnaire was prepared for getting the opinion of 10 experts of the National Iranian Oil Engineering and Construction Company (NIOEC). Note that NIOEC is responsible for the implementation of Iran's infrastructure projects in the field of petroleum refining, petroleum pipelines and depots, as well as joint venture overseas petroleum-related projects. Some of the accomplished projects are as below:

- Construction of Arak refinery

- Construction of Bandar Abbas refinery

- Installation of more than 5000 kilometres crude oil and oil products pipelines

- Installation of more than 170 pump stations

- Installation of more than 10 oil terminals and storage tanks

It is also to be mentioned that all respondents were experts with 10 to 30 years of experience in different areas of oil projects such as project management and engineering. The judgment of every expert on the delay factors was obtained using the semantic variables included in the questionnaire. We accordingly set Fuzzy linguistic scale and triangular fuzzy numbers as shown in Table 2. 
Table 2. Evaluation of the linguistic term set and the corresponding triangular fuzzy numbers (Shen et al. 2010).

\begin{tabular}{lll}
\hline Fuzzy linguistic scale & Evaluation linguistic term set & Triangular fuzzy numbers (a,b,c) \\
\hline$\widetilde{9}$ & Very important & $(7,9,9)$ \\
$\widetilde{7}$ & Important & $(5,7,9)$ \\
$\widetilde{5}$ & Moderate & $(3,5,7)$ \\
$\widetilde{3}$ & Unimportant & $(1,3,5)$ \\
$\widetilde{1}$ & Very unimportant & $(1,1,3)$ \\
\hline
\end{tabular}

Step 2: Calculate the evaluation values of every delay factor according to the triangular fuzzy number: Let $w_{i k}=\left(a_{i k}, b_{i k}, c_{i k}\right)$ denotes the evaluation value of the delay factor $k \in N\{1, \mathrm{~K} n\}$ given expert $i \in M=\{1, \mathrm{~K}, m\}$. Then the fuzzy weight of the delay factor $k$ is defined as:

$$
w_{k}=\left(\alpha_{k}, \beta_{k}, \gamma_{k}\right), \quad k=1,2, \ldots, n
$$

where $\alpha_{k}=\min _{i \in N} a_{i k}, \beta_{k}=\frac{1}{m} \sum_{i=1}^{m} b_{i k}$, and $\gamma_{k}=\max _{i \in N} c_{i k}$.

Step 3: Defuzzification: To obtain the final weight, $S_{k}$, the fuzzy weight of every delay factor is defuzzied using a simple center of the gravity method by Equation (2).f

$$
S_{k}=\frac{\alpha_{k}+\beta_{k}+\gamma_{k}}{3}
$$

Step 4: Set a threshold $\rho$ to select the important delay factors among others: If $S_{k}>\rho$, the delay factor $k$ is retained; Otherwise, the delay factor $k$ is abandoned (Zhang 2017). Note that the value of the threshold $\rho$ depends on the users' preference (Shen et al. 2010). If the users want more delay factors, they can set the threshold small, and vice versa. In this study, we set $\rho=5.5$.

It would be mentioned that a practical consideration facing the researcher is the number of experts their opinions are gathered. There are no hard and fast rules; where the group is homogeneous, then a smaller sample of between ten to fifteen people may yield sufficient results. However, if several groups are involved (e.g. an international study), then a larger sample will likely be needed (Skulmoski et al., 2007).

\subsection{Best-worst method (BWM)}

After identifying delay factors in Iran's oil construction projects, we aim to prioritize these factors based on their importance. In this regard, we use BWM. Here, we briefly describe the steps of BWM that can be used to determine the weights of the delay factors (Rezaei 2016).

Step 1: Determine a set of delay factors. We identified the delay factors using FDM in the previous section. The delay factors set as $\left\{c_{1}, c_{2}, \ldots, c_{n}\right\}$. 
Step 2: Determine the most important (the best) and the least important (the worst) delay factors in each category by getting the opinion of the experts.

Step 3: Determine the preference of the most important (best) delay factor among the other factors using a number between 1 and 9 and by getting the opinion of the experts. The resulting best-to-others $(\mathrm{BO})$ vector would be:

$$
A_{B}=\left(a_{B 1}, a_{B 2}, \ldots, a_{B n}\right)
$$

where, $a_{B j}$ indicates the preference of the most important delay factor $B$ over the delay factor $j$. It is clear that $a_{B B}=1$.

Step 4: Determine the preference of all delay factors over the least important (worst) delay factor using a number between 1 and 9 and by getting the opinion of the experts. The resulting others-to-worst (OW) vector would be:

$$
A_{W}=\left(a_{1 W}, a_{2 W}, \ldots, a_{n W}\right)^{T}
$$

where, $a_{j W}$ indicates the preference of delay factor $\mathrm{j}$ over the least important delay factor $W$. It is clear that $a_{W W}=1$.

Step 5. Find the optimal weights of each delay factor $\left(w_{1}^{*}, w_{2}^{*}, \ldots, w_{n}^{*}\right)$ by solving the following linear programming problem:

$$
\begin{aligned}
& \min \xi \\
& \text { s.t: } \\
& \left|w_{B}-a_{B J} w_{j}\right| \leq \xi, \text { for all } j \\
& \left|w_{j}-a_{j W} w_{W}\right| \leq \xi, \text { for all } j \\
& \sum_{j} w_{j}=1 \\
& w_{j} \geq 0, \text { for all } j
\end{aligned}
$$

Problem (5) is a linear program, which has a unique solution. Solving problem (5), the optimal weights, $\left(w_{1}^{*}, w_{2}^{*}, \ldots, w_{n}^{*}\right)$, and $\xi^{*}$, are obtained. For this model, $\xi^{*}$ can be considered as an indicator of the consistency of the comparisons. Considering the consistency index (Table 3), the consistency ratio is calculated as follows:

$$
\text { Consistency Ratio }=\frac{\xi^{*}}{\text { Consistenct Index }}
$$

$a_{B W}$ is the preference of the most important delay factor over the least important delay factor. Consistency ratio $\in[0,1]$, values close to 0 show more consistency, while values close to 1 show less consistency. 
Table 3. Consistency index table (Rezaei 2016).

\begin{tabular}{llllllllll}
\hline$a_{B W}$ & 1 & 2 & 3 & 4 & 5 & 6 & 7 & 8 & 9 \\
\hline $\begin{array}{l}\text { Consistency Index } \\
(\max \xi)\end{array}$ & 0.00 & 0.44 & 1.00 & 1.63 & 2.30 & 3.00 & 3.73 & 4.47 & 5.23 \\
\hline
\end{tabular}

\section{Findings and discussion}

\subsection{Identification of the initial delay factors in construction projects}

As mentioned above, by an extensive literature review, the initial factors causing delay in construction projects were identified. These factors were categorized into ten groups including owner, contractor, consultant, equipment, labor, materials, design, contract and contractual relations, laws and regulations, and environmental factors. For each category, the subcategories were also determined (Table 1).

\subsection{Implication of FDM}

FDM was adopted to determine the final delay factors in Iran's oil construction projects. To do this, we collected the experts' judgments through a two-round survey. A questionnaire was prepared and sent to the experts of NIOEC to gather their idea about the importance of each delay factor. A list of the possible delay factors in construction projects was presented, and the respondents were asked to rate each factor according to their relative importance as a significant factor (very important, important, moderate, unimportant, and very unimportant). Moreover, the experts were asked to add other appropriate and necessary delay factors not specified in the questionnaire. In this round, a new category named managerial factors was added to the list of delay factors.

For the second round, delay factors and their average scores were sent to the experts, and the experts were asked to determine their opinion on the importance of each factor concerning their average scores. Then we used Equations (1) and (2) to deal with the data and obtain the values in columns 3 to 6 of Table 4. For instance, if an expert rates financial problems of owner as very important, the fuzzy number $(7,9,9)$ is assigned to this factor. We gathered the opinions of 10 experts; therefore, we have 10 fuzzy numbers. To combine these opinions, we used Equation (1), and to obtain the weight of the factor, Equation (2) was applied.

As we chose $\rho=5.5$, the delay factors with the final score of 5.5 or more were selected as the leading delay factors in Iran's oil construction projects. These factors are highlighted in the grey background in Table 4 . 
Table 4. Delay factors in Iran's oil construction projects.

\begin{tabular}{|c|c|c|c|c|c|}
\hline \multirow{2}{*}{ Category } & \multirow[t]{2}{*}{ Delay factor } & \multicolumn{4}{|c|}{ Scores } \\
\hline & & $\begin{array}{l}\text { Min } \\
\left(\alpha_{k}\right)\end{array}$ & $\begin{array}{l}\text { Mean } \\
\left(\beta_{k}\right)\end{array}$ & $\begin{array}{l}\text { Max } \\
\left(\gamma_{k}\right)\end{array}$ & $\begin{array}{l}\text { Final } \\
\left(s_{k}\right)\end{array}$ \\
\hline \multirow[t]{13}{*}{ Owner } & Financial problems and delay in payment & 3 & 6.6 & 9 & 6.2 \\
\hline & Unrealistic contract duration & 3 & 6.6 & 9 & 6.2 \\
\hline & Delay in reviewing and approving documents & 1 & 5 & 9 & 5 \\
\hline & $\begin{array}{l}\text { Slowness in decision making and } \\
\text { administrative bureaucracy }\end{array}$ & 1 & 4.6 & 7 & 4.2 \\
\hline & $\begin{array}{l}\text { Poor communication and coordination with } \\
\text { other parties }\end{array}$ & 1 & 4.6 & 7 & 4.2 \\
\hline & Delay in site delivery & 1 & 4.6 & 9 & 4.9 \\
\hline & $\begin{array}{l}\text { Delay in materials to be supplied by the } \\
\text { owner }\end{array}$ & 3 & 6.6 & 9 & 6.2 \\
\hline & Owner interference & 1 & 5 & 9 & 5 \\
\hline & Types of biding and rewards & 3 & 6.6 & 9 & 6.2 \\
\hline & Ineffective incentives and penalties & 1 & 4.6 & 9 & 4.9 \\
\hline & Frequent change of managers & 1 & 4.6 & 9 & 4.9 \\
\hline & Lack of experience & 1 & 4.6 & 7 & 4.1 \\
\hline & Inappropriate feasibility study of the project & 3 & 6.2 & 9 & 6.1 \\
\hline \multirow[t]{11}{*}{ Contractor } & Financial problems & 1 & 5.8 & 9 & 5.3 \\
\hline & Inadequate experience & 3 & 6.6 & 9 & 6.2 \\
\hline & Poor site management and supervision & 5 & 7.4 & 9 & 7.1 \\
\hline & Rework to correct undesirable work & 3 & 6.2 & 9 & 6.1 \\
\hline & Inappropriate construction methods & 3 & 5.4 & 9 & 5.8 \\
\hline & $\begin{array}{l}\text { Poor communication and coordination with } \\
\text { other parties }\end{array}$ & 1 & 4.6 & 7 & 4.2 \\
\hline & Ineffective project planning and scheduling & 3 & 6.2 & 9 & 6.1 \\
\hline & Problems with subcontractors & 3 & 5.8 & 9 & 5.9 \\
\hline & Weak project management & 5 & 8 & 9 & 7 \\
\hline & $\begin{array}{l}\text { Poor qualification of the contractors' } \\
\text { technical staff }\end{array}$ & 1 & 5.4 & 9 & 5.1 \\
\hline & Improper pricing by contractors to win the bid & 3 & 7.4 & 9 & 6.5 \\
\hline \multirow[t]{8}{*}{ Consultant } & $\begin{array}{l}\text { Weak communication and coordination with } \\
\text { other parties }\end{array}$ & 1 & 4.6 & 7 & 4.2 \\
\hline & Inadequate experience & 3 & 6.6 & 9 & 6.2 \\
\hline & Delay in conducting inspection and testing & 3 & 6.2 & 9 & 6.1 \\
\hline & $\begin{array}{l}\text { Delay in reviewing and approving design, } \\
\text { drawings and ... }\end{array}$ & 1 & 5.4 & 9 & 5.1 \\
\hline & $\begin{array}{l}\text { Ambiguities and mistakes in specifications } \\
\text { and drawings and documents }\end{array}$ & 3 & 5.8 & 9 & 5.9 \\
\hline & Technical and managerial weaknesses & 3 & 6.6 & 9 & 6.2 \\
\hline & Poor contract management & 3 & 5.4 & 9 & 5.8 \\
\hline & Quality assurance/control & 1 & 3.4 & 7 & 3.8 \\
\hline \multirow[t]{6}{*}{ Equipment } & Frequent failure of equipment & 1 & 5 & 9 & 5 \\
\hline & Shortage of equipment & 1 & 6.2 & 9 & 5.4 \\
\hline & Low efficiency of equipment & 3 & 6.2 & 9 & 6.1 \\
\hline & $\begin{array}{l}\text { Inappropriate selection of equipment and } \\
\text { faulty equipment }\end{array}$ & 1 & 6.2 & 9 & 5.4 \\
\hline & Slow mobilization of equipment & 1 & 4.2 & 7 & 4.1 \\
\hline & Lack of high-tech mechanical equipment & 1 & 4.6 & 7 & 4.2 \\
\hline
\end{tabular}




\begin{tabular}{|c|c|c|c|c|c|}
\hline \multirow[t]{5}{*}{ Labor } & Low productivity & 5 & 7.8 & 9 & 7.3 \\
\hline & Low motivation & 3 & 7 & 9 & 6.3 \\
\hline & Shortage of labor & 1 & 4.2 & 9 & 4.7 \\
\hline & Personal differences of employees & 1 & 3 & 7 & 3.7 \\
\hline & Nationality & 1 & 3 & 5 & 3 \\
\hline \multirow[t]{7}{*}{ Materials } & Shortage of materials & 1 & 3.8 & 7 & 3.9 \\
\hline & Delay in delivery of materials & 1 & 4.6 & 9 & 4.9 \\
\hline & Low quality & 1 & 4.6 & 9 & 4.9 \\
\hline & Changes in price & 3 & 7 & 9 & 6.3 \\
\hline & $\begin{array}{l}\text { Changes in the type and characteristics of } \\
\text { materials }\end{array}$ & 1 & 5 & 9 & 5 \\
\hline & Damage of stored materials & 1 & 4.6 & 9 & 4.9 \\
\hline & $\begin{array}{l}\text { Problems with providing materials at current } \\
\text { official prices }\end{array}$ & 1 & 5.4 & 9 & 5.1 \\
\hline \multirow[t]{5}{*}{ Design } & $\begin{array}{l}\text { Mistakes and discrepancies in design } \\
\text { documents }\end{array}$ & 1 & 4.2 & 7 & 4.1 \\
\hline & $\begin{array}{l}\text { Incomplete/conflicts of design drawings } \\
\text { details and specifications }\end{array}$ & 1 & 3.8 & 7 & 3.9 \\
\hline & $\begin{array}{l}\text { Poor use of advanced engineering design } \\
\text { software }\end{array}$ & 1 & 4.6 & 7 & 4.2 \\
\hline & Changes in design & 3 & 6.6 & 9 & 6.2 \\
\hline & $\begin{array}{l}\text { Misunderstanding of owner requirements by } \\
\text { design engineer }\end{array}$ & 3 & 5 & 7 & 5 \\
\hline \multirow{5}{*}{$\begin{array}{l}\text { Contract and } \\
\text { contractual } \\
\text { relations }\end{array}$} & $\begin{array}{l}\text { Mistakes and disputes in the contract } \\
\text { documents }\end{array}$ & 1 & 4.6 & 7 & 4.2 \\
\hline & Changes in orders of contract & 1 & 4.6 & 7 & 4.2 \\
\hline & Lack of communication between the parties & 1 & 4.6 & 7 & 4.2 \\
\hline & Major disputes and negotiations & 1 & 4.6 & 7 & 4.2 \\
\hline & $\begin{array}{l}\text { Inappropriate organizational structure linking } \\
\text { to the project }\end{array}$ & 3 & 75.4 & 9 & 5.8 \\
\hline \multirow{3}{*}{$\begin{array}{l}\text { Laws and } \\
\text { regulations }\end{array}$} & Changes in laws and regulations & 3 & 6.6 & 9 & 6.2 \\
\hline & Weaknesses in the laws and regulations & 1 & 5 & 9 & 5 \\
\hline & Tax laws, tariffs, and customs duties & 1 & 4.6 & 9 & 4.9 \\
\hline \multirow[t]{3}{*}{$\begin{array}{l}\text { Managerial } \\
\text { factors }\end{array}$} & $\begin{array}{l}\text { Absence of a real system for managers' } \\
\text { performance measurement }\end{array}$ & 5 & 7.8 & 9 & 7.3 \\
\hline & $\begin{array}{l}\text { Failure to appoint managers based on their } \\
\text { performance evaluation }\end{array}$ & 5 & 7.4 & 9 & 7.1 \\
\hline & $\begin{array}{l}\text { Lack of feedback in case of any deviations in } \\
\text { time and cost and quality of projects in } \\
\text { governmental management systems }\end{array}$ & 5 & 8.6 & 9 & 7.5 \\
\hline \multirow{8}{*}{$\begin{array}{l}\text { Environment } \\
\text { al factors }\end{array}$} & Unexpected geological conditions & 1 & 4.2 & 9 & 4.7 \\
\hline & Weather conditions & 1 & 3 & 7 & 3.7 \\
\hline & $\begin{array}{l}\text { Incidental events such as flood, earthquake, } \\
\text { and storm }\end{array}$ & 1 & 3.4 & 9 & 4.5 \\
\hline & Sanction & 5 & 7.8 & 9 & 7.3 \\
\hline & Inflation & 5 & 8.2 & 9 & 7.4 \\
\hline & $\begin{array}{l}\text { Economic changes such as changes in } \\
\text { exchange rate }\end{array}$ & 5 & 8.6 & 9 & 7.5 \\
\hline & Problem with neighbors & 1 & 3.8 & 7 & 3.9 \\
\hline & Change in government policies & 1 & 5 & 9 & 5 \\
\hline
\end{tabular}




\subsection{Implication of $B W M$}

After identification of the delay factors in Iran's oil construction projects, these factors were prioritized using BWM. For this purpose, a meeting consisting of the experts was held. The opinion of experts about the best and the worst factors in each category was gathered. Moreover, the preference of the best delay factor among the other factors $\left(A_{B}\right)$, and the preference of all delay factors over the worst delay factor $\left(A_{W}\right)$ were determined. Finally, the optimal weights were obtained by solving the problem (5). Table 5 depicts the results of the implication of BWM.

Table 5. Prioritizing the delay factors in Iran's oil construction projects.

\begin{tabular}{|c|c|c|c|c|}
\hline Category & Delay factor & Weight & Priority & $\begin{array}{l}\text { Rate of } \\
\text { consistency }\end{array}$ \\
\hline \multirow[t]{11}{*}{ Main factors } & Environmental factors & 0.25 & 1 & 0.01 \\
\hline & Managerial factors & 0.15 & 2 & \\
\hline & Consultant & 0.1 & 3 & \\
\hline & Contractor & 0.1 & 3 & \\
\hline & Owner & 0.07 & 4 & \\
\hline & Labor & 0.07 & 4 & \\
\hline & Contract and contractual relations & 0.06 & 5 & \\
\hline & Laws and regulations & 0.06 & 5 & \\
\hline & Equipment & 0.06 & 5 & \\
\hline & Design & 0.05 & 6 & \\
\hline & Materials & 0.02 & 7 & \\
\hline \multirow[t]{5}{*}{ Owner } & $\begin{array}{l}\text { Financial problems and delay in } \\
\text { payment }\end{array}$ & 0.35 & 1 & 0.07 \\
\hline & Types of biding and rewards & 0.21 & 2 & \\
\hline & $\begin{array}{l}\text { Inappropriate feasibility study of the } \\
\text { project }\end{array}$ & 0.21 & 2 & \\
\hline & $\begin{array}{l}\text { Delay in materials to be supplied by the } \\
\text { owner }\end{array}$ & 0.14 & 3 & \\
\hline & Unrealistic contract duration & 0.09 & 4 & \\
\hline \multirow[t]{8}{*}{ Contractor } & Weak project management & 0.29 & 1 & 0.06 \\
\hline & Poor site management and supervision & 0.15 & 2 & \\
\hline & $\begin{array}{l}\text { Ineffective project planning and } \\
\text { scheduling }\end{array}$ & 0.15 & 2 & \\
\hline & $\begin{array}{l}\text { Improper pricing by contractors to win } \\
\text { the bid }\end{array}$ & 0.15 & 2 & \\
\hline & Inadequate experience & 0.07 & 3 & \\
\hline & Problems with subcontractors & 0.07 & 3 & \\
\hline & Inappropriate construction methods & 0.06 & 4 & \\
\hline & Rework to correct undesirable work & 0.06 & 5 & \\
\hline \multirow[t]{4}{*}{ Consultant } & Technical and managerial weaknesses & 0.37 & 1 & 0.1 \\
\hline & Poor contract management & 0.23 & 2 & \\
\hline & Inadequate experience & 0.16 & 3 & \\
\hline & $\begin{array}{l}\text { Ambiguities and mistakes in } \\
\text { specifications and drawings and } \\
\text { documents }\end{array}$ & 0.16 & 3 & \\
\hline
\end{tabular}


Delay in conducting inspection and $0.09 \quad 4$ testing

\begin{tabular}{|c|c|c|c|c|}
\hline Equipment & Low efficiency of equipment & 1 & 1 & \\
\hline Labor & Low productivity & 0.67 & 1 & \\
\hline 80 & Low motivation & 0.37 & 2 & \\
\hline Materials & Changes in price & 1 & 1 & \\
\hline Design & Changes in design & 1 & 1 & \\
\hline $\begin{array}{l}\text { Contract and } \\
\text { contractual } \\
\text { relations }\end{array}$ & $\begin{array}{l}\text { Inappropriate organizational structure } \\
\text { linking to the project }\end{array}$ & 1 & 1 & \\
\hline $\begin{array}{l}\text { Laws and } \\
\text { regulations }\end{array}$ & Changes in laws and regulations & 1 & 1 & \\
\hline \multirow[t]{3}{*}{$\begin{array}{l}\text { Managerial } \\
\text { factors }\end{array}$} & $\begin{array}{l}\text { Lack of feedback in case of any } \\
\text { deviations in time and cost and quality } \\
\text { of projects in governmental management } \\
\text { systems }\end{array}$ & 0.64 & 1 & \multirow[t]{3}{*}{0.06} \\
\hline & $\begin{array}{l}\text { Absence of a real system for managers' } \\
\text { performance measurement }\end{array}$ & 0.24 & 2 & \\
\hline & $\begin{array}{l}\text { Failure to appoint managers based on } \\
\text { their performance evaluation }\end{array}$ & 0.1 & 3 & \\
\hline \multirow{3}{*}{$\begin{array}{l}\text { Environmental } \\
\text { factors }\end{array}$} & Sanction & 0.57 & 1 & \multirow[t]{3}{*}{0.14} \\
\hline & $\begin{array}{l}\text { Economic changes such as changes in } \\
\text { exchange rate }\end{array}$ & 0.29 & 2 & \\
\hline & Inflation & 0.14 & 3 & \\
\hline
\end{tabular}

\subsection{Discussion}

Findings show that the fundamental group causing delays in oil construction projects are environmental category, followed by managerial factors, consultant, contractor, owner, labor, contract and contractual relations, laws and regulations, equipment, design, and materials.

Environmental factors are the most significant factors causing delay in Iran's oil construction projects. Environment's influence is found to be due to sanction, economic changes, and inflation. This finding is indeed similar to the findings of Sweis et al. (2018a) that identified sanction as one of the most causes of delay in strategic industrial projects in Iran.

Managerial factors are found to be the second most significant factors affecting schedule performance in Iran's construction projects. As far as the oil construction projects are managed by governmental systems, there is not any real feedback in case of deviations in time and cost, and quality of the projects, managers' performance is not measured carefully, and project managers are not evaluated based on their real performance. This finding is a new detection which has not been reported on Iran's construction projects so far.

Among different causes of delay, financial problems, and delay in payment by owner, weak project management by contractor, and technical and managerial weaknesses of consultant were ranked as the most critical delay causes. Similarly, low efficiency of equipment, low productivity of labor, changes in price of material, changes in design, inappropriate 
organizational structure linking to the project, and changes in laws and regulations were identified as other crucial causes of delay in Iran's oil construction projects.

The results of the present study are in close agreement with that of earlier studies in developing countries. Comparison of the results of the study with the previous research indicated that owner's financial problems were found to be the most critical causes of delay in oil and gas construction industry of the countries such as Iran and India (Fallahnejad, 2013; Prasad et al. 2019). As stated by Zakeri et al. (1996) and Sandhyavitri (2019), changes in design and specifications are one of the significant causes of delay in oil construction projects in Iran, and Indonesia. Moreover, our findings are supported by prior research conducted by Zakeri et al. (1996), and Ravand and Salahi (2011) that low efficiency of equipment, and low productivity of labor are critical delay factors in construction projects in Iran.

These findings are also consistent with the previous study that ineffective planning and scheduling by contractor was identified as one of the most three important delay factors in EPC petrochemical projects in Vietnam (Pham and Hadikusumo, 2014). Moreover, poor site management and supervision, and ineffective project planning and scheduling were identified as the main causes of delay in oil and gas construction projects in Oman (Ruqaishi and Bashir, 2014). Policy in bidding tender to the lowest price was identified as one of the five important delay factors in oil construction projects of Malaysia (Abdullah et al., 2018). Furthermore, the most important reasons for delays from contractors in construction projects was poor site management and supervision in Thailand's oil and gas platform projects (Gomarn and Pongpeng, 2018). Finally, there is consistency between the current study and Aljamee et al. (2020) in terms of ranking types of biding and rewards, and weak project management in the top five most important causes of delay in Iraq's petroleum industry.

Based on the results of this study and other similar works in this area, financial problems are one of the most important problems in oil and gas construction projects. Financial problems of owners lead to problems for contractors such as paying the wages of workers, employees, and subcontractors, paying the rent for machinery and equipment, and buying needed materials for the project. Therefore, owners should allocate enough financial resources for the projects before the tender phase. They should pay the contractor based on the schedule and at the right time (Khoshgoftar et al., 2010).

Weak project management by contractor and technical and managerial weaknesses by consultant were identified as key delay factors. Hence, owners are supposed to ensure the employment of competent and qualified personnel. Construction managers should have the necessary experience and qualifications in oil construction and project management. In this way, developing training programs in the different sectors of construction will be useful (Rachid, 
2018). A high degree of training of employees would reduce the criticality of several problems such as low productivity of labors (Bajjou and Chafi, 2018). Training programs could provide workers with the required techniques and skills concerning scheduling, cost and time control, and risk analysis (Bajjou and Chafi, 2018).

\section{Conclusions and recommendations}

This study quantitatively investigated the selection and prioritization of causes of delay in Iran's oil construction projects. For this purpose, by reviewing the literature we firstly identified the delay factors in 10 categories. Then using FDM and by collecting the opinion of Iranian experts in the field of oil project management through a two-round survey, a total of 75 potential delay factors were identified and categorized into 11 groups:

We classified the delay factors in 11 categories: owner, contractor, consultant, equipment, labor, materials, design, contract and contractual relations, laws and regulations, managerial factors, and environmental factors. In the next step, we used BWM to prioritize the factors and determine the most important ones. The results show that environmental and managerial factors are the most important delay factors in Iran's oil construction projects.

Based on our results, we recommend the followings in order to minimize and control the delay in Iran's oil construction projects:

- In consideration of financial problems and delay in payment by owners, initial cost estimates should be as accurate as possible. Correct estimation would allow owners to ensure that the required funds for executing the projects are sourced in right time and made available when required.

- Based on weak project management by contractor, only the contractor's financial proposal should not be considered for selecting the contractors; rather, less weight to prices and more weights to the capabilities and past performance of contractors should also be assigned.

- Taking into account technical and managerial weaknesses of consultants, developing human resources may apply to consultants who usually lack adequate managerial skills.

- Concerning the low efficiency of equipment, advanced equipment should be used in oil construction projects; if not available, it is essential to check the availability of necessary construction equipment.

- Attending to low productivity of labors, developing human resources in the oil construction industry through proper training should be taken into consideration.

- Addressing changes in the price of materials, price differences could be considered in the contract. 
- Regarding changes in design, it should be considered that owners may demand some design changes during construction but to a limit having no adverse effects on the activities on the critical path.

- Considering inappropriate organizational structure linking to the project, the appropriate organizational structure should be linked to the project. There would be specific projects that cannot be managed by certain types of organizational structures. For instance, it is challenging to execute quick impact projects in a functional organizational structure due to the slow decision making processes and bureaucracies associated with such a structure.

- Respective of lack of feedback in case of deviations in time and cost, and quality of projects in governmental management systems of Iran, it is recommended that oil projects left to the private sector.

The oil and gas industry and its projects are tightly related to the country's economy and one of the public budget income resources in developing countries. Oil and gas projects are also assumed as mega projects in the infrastructure of any oil country. Identification and prioritizing of delay factors in construction projects helps the management and project team to plan for right responses to these risks. Therefore, the findings of this research will provide a beneficial approach for oil construction management to deliver projects on time, and improve the construction projects productivity. Oil construction project managers would understand any possible delays and risks during the construction phase better, and formulate delay mitigation strategies properly. (Kassem et al., 2019).

Nevertheless, this study is not without its limitations. The consistency of the findings reported here can be improved by increasing the number of experts. It is also suggested to gather and investigate the opinion of different stakeholders, including owners, contractors, and consultants.

\section{Acknowlegments}

This research was supported by the National Iranian Oil Engineering and Construction Company (NIOEC).

\section{References}

Abbasi, O., Noorzai, E., Gharouni.J, K., and Golabchi, M. (2020), Exploring the Causes of Delays in Construction Industry, Journal of Architectural Engineering, 26(3).

Abbasnejad, B. and Izadi-Moud, H. (2013), Construction Delays in Iranian Civil Engineering Projects : An Approach to the Financial Security of Construction Business, Life Science Journal, 10(2), 
2632-2637.

Abdullah, M.S., Alaloul, W.S., Liew M.S. and Mohammed B.S. (2018), Delays and Cost Overruns Causes During Construction of Palm Oil Refinery Projects, International Conference on Civil, Offshore \& Environmental Engineering, Malaysia, 1-8.

Al-Hazim, N., Salem Z.A. and Ahmad, H. (2017), Delay and Cost Overrun in Infrastructure Projects in Jordan, Procedia Engineering, 182, 18-24.

Aljamee, H., Naeem, S. and Bell, A. (2020), The causes of project delay in Iraqi petroleum industry: A case study in Basra Oil Company, Journal of Transnational Management, 25(1), 57-70.

Al-Khalil, M.I. and Al-Ghafly, M.A. (1999), Important Causes of Delay in Public Utility Projects in Saudi Arabia Important Causes of Delay in Public Utility Projects in Saudi Arabia, Construction Management and Economics, 17(5), 647-55.

Al-Maktoumi, I.S., Rahman Khan, F., Al Maktoumi, A.R.S. (2020), Assessing the Factors Causing Project Completion Delays in the Construction Sector of Oman Uisng SEM-PLS, Humanities \& Social Sciences Reviews, 8(3), 900-12.

Alsuliman, J.A. (2019), Causes of delay in Saudi public construction projects, Alexandria Engineering Journal,58, 801-808.

Andi. (2006), The Importance and Allocation of Risks in Indonesian Construction Projects, Construction Management and Economics, 24, 69-80.

Arditi, D., Akan, G.T. and Gurdamar, S. (1985), Reasons for Delays in Public Projects in Turkey, Construction Management and Economics, 3(2), 171-81.

Assaf, S.A. and Al-Hejji, S. (2006), Causes of Delay in Large Construction Projects, International Journal of Project Management, 24(4), 349-57.

Atafar A., Eghbali M. (2013), Analyzing the Factors Influencing Delay of Projects in Zone 3 of Iranian Gas Transmission Company”, Journal of Industrial Management, 5(2), 85-102.

Aziz, R.F. and Abdel-Hakam, A.A. (2016), Exploring Delay Causes of Road Construction Projects in Egypt, Alexandria Engineering Journal, 55(2), 1515-39.

Aziz, R.F. (2013), Ranking of Delay Factor in Construction Projects After Egyption Revolution, Alexandria Engineering Journal, 52(3), 387-406.

Doloi, H., Sawhney, A., Iyer, K.C. and Rentala, S. (2012), Analysing Factors Affecting Delays in Indian Construction Projects, International Journal of Project Management, 30(4), 479-89.

Fallahnejad, M.H. (2013), Delay Causes in Iran Gas Pipeline Projects, International Journal of Project Management 31(1), 136-46.

Faridi, A.S., Monir, S. and Sayegh, E. (2006), Construction Management and Economics Significant Factors Causing Delay in the UAE Construction Industry, Construction Management and Economics, 24, 1167-76.

Fish, L.S., and Busby, D.M. (1996). The Delphi method. In D.H. Sprenkle and S.M. Moon (Eds.), Research methods in family therapy, The Guilford Press.

Gebrehiwet, T. and Luo, H. (2017), Analysis of Delay Impact on Construction Project Based on RII and 
Correlation Coefficient: Empirical Study, Procedia Engineering, 196, 366-74.

Gomarn, P. and Pongpeng, J. (2018), Causes of construction delay from contractors and suppliers in Thailand's oil and gas platform projects, The 4th International Conference on Engineering, Applied Sciences and Technology, 192.

Hosaini, S.B. and Singla S. (2019), Significant Factors of Delay in Construction Projects in Afghanistan, International Journal of Innovative Technology and Exploring Engineering, 8(95), $1060-69$.

Hatmoko, J.U.D. and Khasani, R.R. (2019), Mapping Delay Risks of EPC Projects: A Case Study of A Platform and Subsea Pipeline of An Oil and Gas Project, Annual Conference on Industrial and System Engineering.

Kassem, M.A., Khoiry, M.A. and Hamzah, N. (2019), Risk Factors in Oil and Gas Construction Projects in Developing Countries : A Case Study, International Journal of Energy Sector Management.

Kharashi, A.A, Skitmore, M., Al-kharashi, A. and Skitmore, M. (2009), Construction Management and Economics Causes of Delays in Saudi Arabian Public Sector Construction Projects Causes of Delays in Saudi Arabian Public Sector Construction Projects, Construction Management and Economics, 27, 3-23.

Koshgoftar, M., Abu-Bakar, A.H. and Osman, O. (2010), Causes of Delays in Iranian Construction Projects, The International Journal of Construction Management. 10(2), 53-69.

Kog, Y.C. (2019), Construction Delays in Indonesia, Malaysia, Thailand, and Vietnam, Practice Periodical on Structural Design and Construction. 24(3).

Latif, Q.B.A.I., Al-Saadi, A.M.D., Rahman, I.A. (2019), Identification of Delay Factor in Oman Construction Industry, International Journal of Sustainable Construction Engineering and Technology, 10(1), 34-45.

Le-Hoai, L, Lee, Y.D. and Lee, J.Y. (2008), Delay and Cost Overruns in Vietnam Large Construction Projects: A Comparison with Other Selected Countries, KSCE Journal of Civil Engineering, 12(6), $367-77$.

Marzouk, M.M. and El-Rasas T.I. (2014), Analyzing Delay Causes in Egyptian Construction Projects, Journal of Advanced Research, 5(1), 49-55.

Mezher, T.M. and Tawil, W. (1998), Causes of delays in the construction industry in Lebanon, Engineering, Construction and Architectural Management, 5(3), 252-60.

Mohammad, M.F., Price, A. (2005), Multi-cultural complexity impact on procurement within the oil and gas sector, The First International Conference on Built Environment Complexity.

Muneeswaran, G., Manoharan, P., Awoyera, P.O. and Adesina, A. (2020), A statistical approach to assess the schedule delays and risks in Indian construction industry, International Journal of Construction Management, 20(5), 450-461.

Murray, T.J., Pipino, L.L. and Gigche, J.P.V. (1985), A pilot study of fuzzy set modification of Delphi, Human Systems Management, 5(1), 76-80.

Norouzi, A., and Ghayur-Namin, H. (2019), A Hybrid Fuzzy TOPSIS - Best Worst Method for Risk 
Prioritization in Megaprojects, Civil Engineering Journal, 5(6), 76-80.

Odeh, A.M. and Battaineh, H.T. (2001), Causes of Construction Delay: Traditional Contracts, International Journal of Project Management, 20(1): 67-73.

Oyegoke, A.S. and Kiyumi, N.A. (2017), The Causes, Impacts and Mitigations of Delay in Megaprojects in the Sultanate of Oman, Journal of Financial Management of Property and Construction, 22(3): $286-302$.

Pham, L.H. and Hadikusumo, H. (2014), Schedule Delays in Engineering, Procurement, and Construction Petrochemical Projects, International Journal of Energy Sector Management, 8(1), $3-26$.

Prasad, K.V., Vasugi, V., Venkatesan, R., and Bhat, N. (2019), Analysis of causes of delay in Indian construction projects and mitigation measures, Journal of Financial Management of Property and Construction, 24(1), 58-78.

Ravand M., Salai A. M. (2011), Investigating the Causes of Delay in Performing Oil and Gas Industrial Projects of the National Iranian South Oil Company, Industrial Management (Islamic Azad University, Sanandaj Branch), 17, 43-57.

Rezaei, J. (2016), Best-Worst Multi-Criteria Decision-Making Method: Some Properties and a Linear Model, Omega, 64, 126-30.

Razi, P.Z., Ali, M.I., Ramli, N.I. (2019), AHP-Based Analysis of the Risk assessment Delay Case Study of Public Road Construction Project: An Emprical Study, Journal of Engineering Science and Technology, 14(2), $875-91$.

Ruqaishi, M. and Bashir, H.A. (2014), Causes of Delay in Construction Projects in the Oil and Gas Industry in the Gulf Cooperation Council Countries : A Case Study, Journal of Management in Engineering, 31(3), 1-8.

Salama, M., Hamid, M.A.E. and Keogh, B. (2008), Investigating the Causes of Delay Within Oil and Gas Projects in the UAE, Procs 24th annual ARCOM Conference, United Kingdom, 819-27.

Sambasivan, M., and Soon, Y.W. (2007), Causes and Effects of Delays in Malaysian Construction Industry, International Journal of Project Management, 25(5), 517-26.

Shen, Y.C., Chang, S.H., Lin, G.T.R. and Yu, H.C. (2010), A Hybrid Selection Model for Emerging Technology, Technological Forecasting and Social Change, 77 (1), 151-166.

Skulmoski, G.J., Hartman, F.T., Krahn, J. (2007), The Delphi Method for Graduate Research, Journal of Information Technology Education, 6, 1-21.

Suppramaniam, S.U.Kumar, Ismail, S. and Suppramaniam, S. (2018), Causes of Delay in the Construction Phase of Oil and Gas Projects in Malaysia, International Journal of Engineering \& Technology, 7, 203-9.

Sweis, G., Sweis, R., Hammad, A.A. and Shboul, A. (2008), Delays in Construction Projects: The Case of Jordan, International Journal of Project Management, 26(6), 665-74.

Sweis, R., Moarefi, A., Hoseini-Amiri, S.A. and Moarefi, S. (2018a), Delay factors of the schedule of strategic industrial projects, International Journal of Building Pathology and Adaptation. 
Sweis, R., Moarefi, A., Hoseini-Amiri, S.A., Moarefi, S., Saleh, R. (2018b), Causes of delay in Iranian oil and gas projects: a root cause analysis, International Journal of Energy Sector Management.

Tavakolan, M., Etemadinia, H. (2017), Fuzzy Weighted Interpretive Structural Modeling: Improved Method for Identification of Risk Interactions in Construction Projects, Journal of Construction Engineering Management, 143(11).

Toor, S.U.R., Ogunlana, S.O. (2008), Problems Causing Delays in Major Construction Projects in Thailand, Construction Management and Economics, 26(4), 395-408.

Thuyet, N.V., Ogunlana, S.O. and Dey, P.K. (2007), Risk Management in Oil and Gas Construction Projects in Vietnam, International Journal of Energy Sector Management, 1(2), 175-94.

Wuala, H.D., and Rarasati, A.D. (2020), Causes of delays in construction project for developing Southeast Asia countries, IOP Conf. Series: Materials Science and Engineering, 830.

Zakeri, M. Olomolaiye, P.O., Holt, G.D. and Harris, F.C. (1996), A Survey of Constraints on Iranian Construction Operatives' Productivity A Survey of Constraints on Iranian Construction Operatives' Productivity, Construction Management and Economics, 14, 417-26.

Zarei, B., Sharifi, H. and Chaghouee, Y. (2017), The Management of Operations Delay Causes Analysis in Complex Construction Projects : Delay Causes Analysis in Complex Construction Projects : A Semantic Network Analysis Approach, Production Planning \& Control, 1-12.

Zhang, J. (2017), Evaluating Regional Low-Carbon Tourism Strategies Using the Fuzzy DelphiAnalytic Network Process Approach, Journal of Cleaner Production, 141, 409-19. 